\title{
Communication
}

[Comunicação]

\section{Investigation of Salmonella spp. in free-range chickens (Gallus gallus domesticus) in Southern Rio Grande do Sul}

\author{
[Pesquisa de Salmonella spp. em galinhas coloniais (Gallus gallus domesticus) no
} sul do Rio Grande do Sul]

\section{R. Zamboni ${ }^{\circledR}$, T.S. Alberti ${ }^{\circledR}$, F.R. Venancio ${ }^{\circledR}$, T. Ramires ${ }^{\circledR}$, W.P. Silva ${ }^{\circledR}$, G.Á. Vargas ${ }^{\circledR}$, S.R.L. Ladeira ${ }^{\circledR}$, M.B. Raffi® ${ }^{\circledR}$, E.S.V. Sallis ${ }^{\circledR}$}

Universidade Federal de Pelotas, Faculdade de Veterinária, Capão do Leão, RS, Brasil

\begin{abstract}
Salmonellosis is a disease caused by bacteria of the genus Salmonella and is considered the main foodborne disease in humans. It is associated with the consumption of poultry, eggs, raw meat, and dairy (Gast, 2008; De Carli et al., 2017). Salmonella spp. are highly pathogenic, infecting humans and a wide variety of domestic and wild animals. The main factor that maintains these pathogens in the environment is carrier animals. Transmission occurs both horizontally and vertically (De Carli et al., 2017).
\end{abstract}

The genus Salmonella has more than 2500 serologically distinguishable variants (serotypes) (Gast, 2008; De Carli et al., 2017). Among the different serotypes, Salmonella enterica subsp. enterica of the serotype Gallinarum ( $S$. Gallinarum) has two biovars adapted to birds, Gallinarum and Pullorum, which are causative agents of fowl typhoid (FT) and pullorum disease (PD), respectively (Gast, 2008; Barrow and Freitas Neto, 2011; Barrow et al., 2012; Wigley, 2017).

FT and PD are diseases widely distributed worldwide, primarily in developing countries (Barbour et al., 2015) where increased antimicrobial resistance has become a problem (Penha Filho et al., 2016). These diseases are responsible for significant economic losses to the national poultry industry (De Carli et al., 2017). Research related to salmonellosis in poultry farms in Brazil is mostly conducted in industrial farms. Therefore, little is known about the occurrence of Salmonella spp. in alternative locations (Gomes Filho et al., 2014).
Considering the economic impact of salmonellosis on poultry and the scarcity of data on poultry farms, the objective of this study was to investigate the occurrence of Salmonella spp. in colonial chickens sent to the Laboratorio Regional de Diagnóstico of the Faculdade de Veterinária of the Universidade Federal de Pelotas (LRD/FV/UFPel).

The research on Salmonella spp. was carried out through histopathological, microbiological and molecular analyzes (polymerase chain reaction [PCR]) of samples from domestic chicken organs (Gallus gallus domesticus). The organ samples were collected from 12 domestic chickens from free-range farms between 2017 and 2019 and sent for necropsy to the LRD/FV/UFPel. Clinical signs of the chickens included diarrhea, apathy, anorexia, weight loss, and death. Information on the type of breeding, management, and their health was noted in the necropsy findings.

The 12 chickens included in the study originated from six properties, of which five were extensive and one was semi-intensive, located in the municipalities of Pelotas and Piratini. Only the farm with semi-intensive rearing of free-range chickens which produced and sold eggs had protocols for vaccination, deworming, and periodic sanitary management of the facilities, according to the National Poultry Health Program (PNSA - Plano Nacional de Sanidade Avícola; Brasil, 2009). The other properties had poultry rearing for subsistence only. According to data provided by the breeders, a deworming protocol was sporadically carried out in these 
properties and if sick birds were observed, they were administered varied and nonspecific antibiotics accordingly.

Macroscopically, the main lesion observed in the 12 necropsied chickens was hepatomegaly, which was mild to severe. In seven cases, there were multiple white lesions on the capsular and cut surfaces of the analyzed livers (Fig. 1A). White nodules in the cardiac muscle were observed in three cases (Fig. 1B). During necropsy, fragments were collected from all the organs and fixed in $10 \%$ buffered formalin for histopathological examination. Liver, heart, and intestine fragments (cecum) were collected under refrigeration for microbiological analysis. Microscopically, hepatic and cardiac lesions were characterized by focal areas of necrosis, surrounded by heterophiles, lymphocytes, and plasma cells (Fig. 2A and 2B). There were no significant histopathological lesions in the other organs.
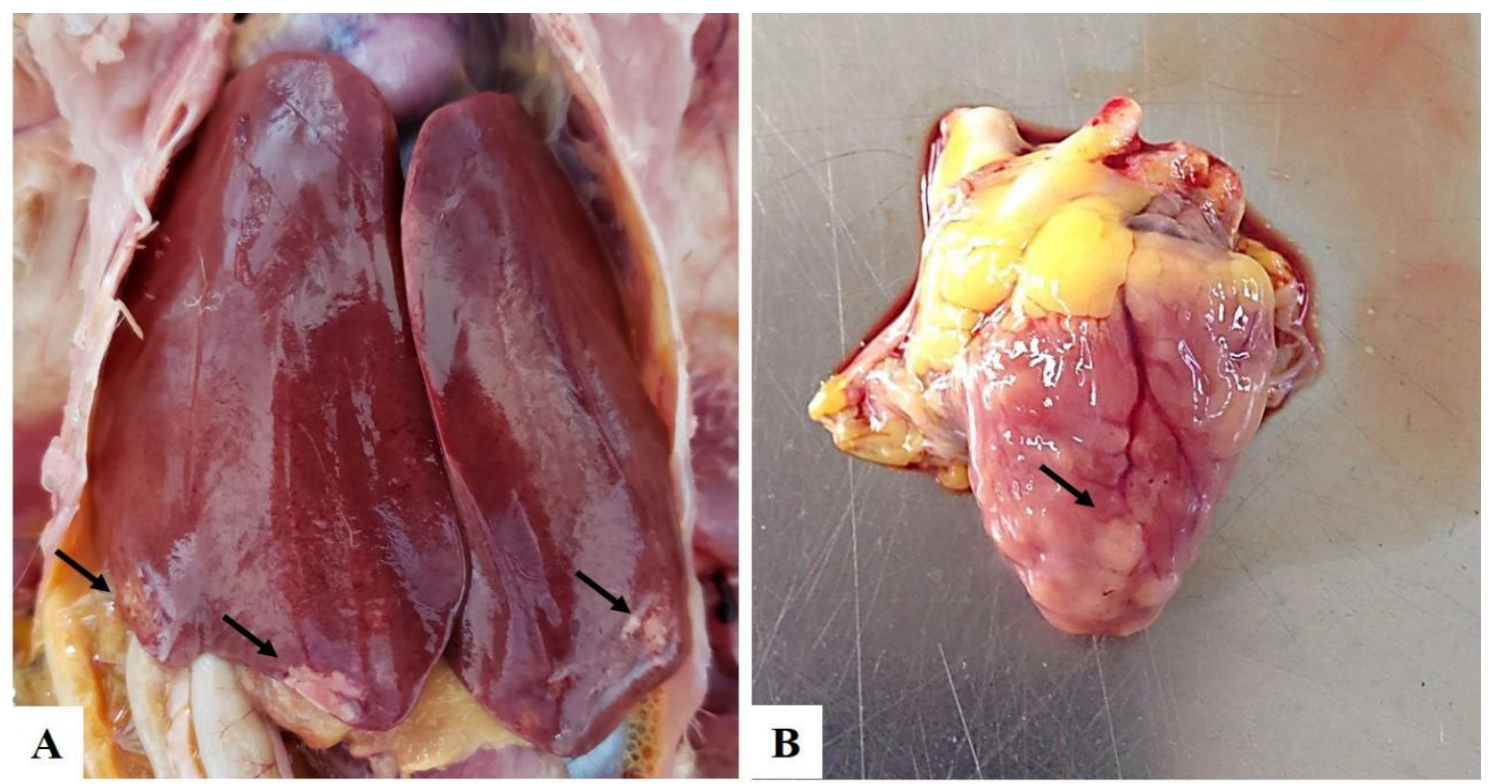

Figure 1. Macroscopic lesions of salmonellosis in necropsied colonial hens at LRD/FV/UFPel. 1A. Liver showing white lesions on the capsular surface (arrows). 1B. Heart with white, multifocal to coalescent nodules in the pericardium (arrow).
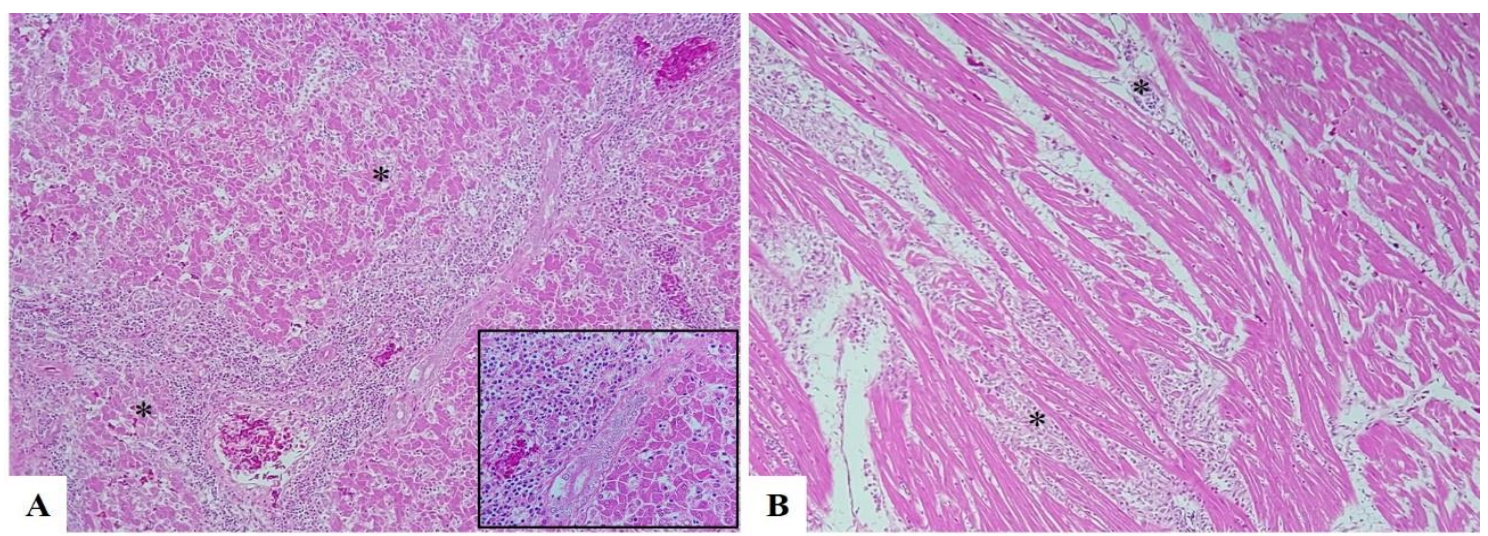

Figure 2. Histopathological lesions of fowl typhoid and pullorum disease in necropsied colonial hens at LRD/FV/UFPel. 1A. Liver showing multifocal and random areas of necrosis (asterisks), surrounded by an intense inflammatory infiltrate of heterophiles, lymphocytes and plasmocytes (inset). HE, obj. 10x; inset HE, obj. 40×. 1B. Cardiac lesion showing inflammatory infiltrate (asterisks), similar to that observed in the liver, in the midst of cardiomyocytes. HE, obj. 10×. 
The microbiological analysis of the necropsy samples was performed via individual seeding of each organ on MacConkey agar (MCA) (MacConkey Agar - Kasvi) and Brilliant green agar (BGA) (Brilliant Green Agar USP - Kasvi). The results were interpreted after $24 \mathrm{~h}$ of incubation at $37^{\circ} \mathrm{C}$. Subsequently, bacterial colonies were subjected to biochemical tests of sulfate indole motility, triple sugar iron agar, Simmons citrate, urea, ornithine, glucose, sucrose, lactose, arabinose, dulcitol, rhamnose, sorbitol, mannitol, maltose, trehalose, and gelatin, according to Quinn et al. (1994) for the characterization of microorganisms.

After the incubation period, the 12 samples presented small and colorless non-fermenting lactose bacterial colonies in MCA, while white to red colonies surrounded by red zones were observed in BGA, displaying the characteristics compatible with Salmonella spp. During the biochemical analysis of the 12 necropsy isolates, 10/12 samples were compatible with $S$. Gallinarum, while 2/12 were compatible with $S$. Pullorum.

The bacterial colonies suggestive of Salmonella spp. obtained from the microbiological analysis were sent to the Laboratory of Food Microbiology, Department of Science and Technology Agroindustrial of UFPel for genotypic identification. Colonies with morphological characteristics of Salmonella spp. were grown in soybean tryptone broth and incubated at $37^{\circ} \mathrm{C}$ for $24 \mathrm{~h}$, with the goal of DNA extraction using the glass pearl technique (Green and Sambrook, 2012). The DNA was quantified by spectrometry (Eppendorf Bio Spectrometer ${ }^{\circledR}$ kinetic) and the samples showed purity values between 1.4 and 1.8 (ratio 260/280nm).

Genotypic identification was performed using the PCR technique in a thermocycler to identify the hilA gene, which is specific to the Salmonella genus and amplifies as a 413 base pair product. The reaction was conducted following the conditions and using the primers previously described by Crăciunas et al. (2012). For each reaction, $12.5 \mathrm{~mL}$ of $2 \times$ GoTaq ${ }^{\circledR}$ Green Master Mix (Promega), 10 pmol of forward and reverse primers, $20 \mathrm{ng}$ of DNA, and ultra-pure water were added for a final volume of $25 \mu \mathrm{L}$. PCR was performed with the following conditions: $94^{\circ} \mathrm{C}$ for $4 \mathrm{~min}$ for initial denaturation, followed by 30 cycles of $94^{\circ} \mathrm{C}$ for $1 \mathrm{~min}, 63^{\circ} \mathrm{C}$ for $1 \mathrm{~min}$, and $72^{\circ} \mathrm{C}$ for $1 \mathrm{~min}$. The final extension was $72^{\circ} \mathrm{C}$ for $10 \mathrm{~min}$. As the positive control, S. Typhimurium DNA (ATCC 14028) was used accordingly. As the negative control, Escherichia coli DNA (ATCC 25922) was used, and ultra-pure water was an internal reaction control. In the molecular analysis (PCR), the presence of DNA from bacteria of the genus Salmonella was confirmed in $11(91.7 \%)$ of the 12 suspected samples, Thus, in the present study, Salmonella spp. were confirmed in 11 samples analyzed by PCR. The isolation index of bacteria of the genus Salmonella is higher in symptomatic birds (acute phase), since it is easily isolated from practically all organs and feces when compared with samples from asymptomatic birds or cloacal swabs (Barrow et al., 2012; Manual..., 2019).

Gallinarum and Pullorum biovars are widespread, mainly in developing countries (Barbour et al., 2015). In Brazil's commercial poultry establishments in the last 5 years, 112 outbreaks of FT $(90.3 \%)$ and 12 of PD (9.7\%) were reported to OIE. From these, $48.2 \%$ of cases of FT and $25.0 \%$ of cases of PD occurred in the state of Rio Grande do Sul (Fowl..., 2020). In the present study, from the 11 isolates confirmed by PCR, 10/11 and $1 / 11$ were biochemically compatible with $S$. Gallinarum and $S$. Pullorum, respectively. The main form of the infection of poultry by biovar Gallinarum occurred by horizontal transmission, whereas for the biovar Pullorum, vertical transmission was more responsible for the spread of the pathogen (Barrow and Freitas Neto, 2011; Barrow et al., 2012). The main forms of infection of Salmonella in chickens on the properties analyzed in the present study likely occurred either by direct contact with wild animals or by the introduction of poultry from different locations, such as in cases associated with the habit of exchanging embryonated eggs with the producers or with the purchase of commercial lines without certified origin.

In the five poultry farms with an extensive breeding system, the chickens were raised freely along with other birds of different categories and species, with some facilities available such as perch and cages. Sporadically, deworming protocols were applied in some of the farms, with no other sanitary management being carried out both in the birds and in the environment in 
which they were allocated. In this breeding system, because of the lower use of facilities and sanitary control, the goal was to create more rustic strains that were considered more resistant to a series of pathogens (Gomes Filho et al., 2014). However, the intercropping of poultry of different ages and species along with the direct contact of domestic birds with wild animals and other vectors, as well as failures in sanitary management, predisposed the chickens to infection by Salmonella spp. (Barrow and Freitas Neto, 2011; Gomes Filho et al., 2014), as shown by factors present in the analyzed poultry farms and possible condition of predisposition to infection of these chickens.
In conclusion, the results obtained in the present study demonstrated a high frequency of isolation of Salmonella Gallinarum biovar Gallinarum in symptomatic free-range chickens reared in an extensive creation sent to the LRD/FV/UFPel. In addition, epidemiological data demonstrated that Salmonella Gallinarum infection in the animals in this study was associated with contact with wild birds and failures in sanitary management.

Keywords: Backyard chickens, fowl typhoid, pullorum disease, Salmonella spp.

\section{RESUMO}

Salmonelose é uma doença causada por bactérias do gênero Salmonella, com importância para saúde pública e animal. Dentre os sorotipos hospedeiro-específicos, destaca-se o Gallinarum, que possui os biovares Gallinarum e Pullorum adaptados às aves e amplamente difundidos pelo mundo. Os dados sobre a ocorrência de Salmonella spp. em criações avícolas alternativas no Brasil são escassos. $O$ objetivo deste estudo foi pesquisar a ocorrência de Salmonella spp. em galinhas coloniais encaminhadas para necropsia ao LRD/FV/UFPel. Foram realizadas análises histopatológicas, microbiológicas $e$ moleculares das colônias bacterianas isoladas de 12 amostras de órgãos de galinhas domésticas dos municípios de Pelotas e Piratini, no Rio Grande do Sul. Na análise microbiológica, foram isoladas bactérias do gênero Salmonella sorotipo Gallinarum das 12 amostras, sendo 10/12 bioquimicamente compatíveis com biovar Gallinarum e 2/12 com biovar Pullorum. Na análise molecular PCR 11/12, 91,7\% foram identificadas genotipicamente como Salmonella spp. O presente estudo demonstrou uma elevada frequência de isolamento de Salmonella Gallinarum biovar Gallinarum em aves sintomáticas criadas em regime extensivo. Além disso, os dados epidemiológicos das aves analisadas demonstram que a infecção por Salmonella Gallinarum nesses casos está associada ao contato com aves silvestres $e$ falhas de manejo sanitário.

Palavras-chave: galinhas caipiras, tifo aviário, pulorose, Salmonella spp.

\section{REFERENCES}

BARBOUR, E.K.; AYYASH, D.B.; ALTURKISTNI, W. et al. Impact of sporadic reporting of poultry Salmonella serovars from selected developing countries. J. Infect. Dev. Ctries., v.9, p.1-7, 2015.

BARROW, P.; FREITAS NETO, O.C. Pullorum disease and fowl typhoid-new thoughts on old diseases: a review. Avian Pathol., v.40, p.1-13, 2011.

BARROW, P.A.; JONES, M.A.; SMITH, A.L. et al. The long view: Salmonella - the last forty years. Avian Pathol., v.41, p.413-420, 2012.
BRASIL, Ministério da Agricultura, Pecuária e Abastecimento, 2009. PNSA: Programa Nacional de Sanidade Avícola. Manual de Legislação: programas nacionais de saúde animal do Brasil/Ministério da Agricultura, Pecuária e Abastecimento. Secretaria de Defesa Agropecuária. Departamento de Saúde Animal. Brasília: MAPA/SDA/DSA, pp. 171-241.

CRĂCIUNAŞ, C.; KEUL, A.L.; FLONTA, M. et al. DNA-based diagnostic tests for Salmonella strains targeting hilA, agfA, spvC and sef genes. J. Environ. Manag., v.95, p.15-18, 2012. 
DE CARLI, S.; GRÄF, T.; KIPPER, D. et al. Molecular and phylogenetic analyses of Salmonella Gallinarum trace the origin and diversification of recent outbreaks of fowl typhoid in poultry farms. Vet. Microbiol., v.212, p.80-86, 2017.

FOWL typhoid and pullorum diseases. World Animal Health Information Database (WAHID). Paris: OIE, 2020.

GAST, R.K. Bacterial diseases: Salmonella infection. In: SAIF, Y.M.; FADLY, A.M.; GLISSON, J.R. et al. (Eds.). Diseases of poultry. Oxford: Blackwell Publishing, 2008. p.619-636.

GOMES FILHO, V.J.R.; TEIXEIRA, R.S.C.; LOPES, E.S. et al. Pesquisa de Salmonella spp. em galinhas criadas em fundo de quintal (Gallus gallus domesticus) e ovos comercializados nas feiras livres na cidade de Fortaleza, Ceará. Semin. Cienc. Agrar., v.35, p.1855-1864, 2014.

GREEN, M.R.; SAMBROOK, J. Molecular cloning: a laboratory manual. 4.ed. New York: Cold Spring Harbor Laboratory Press, 2012.
MANUAL of diagnostic tests and vaccines for terrestrial animals 2019 - fowl typhoid and pullorum disease. Paris: OIE, 2019. Chap.3.3.11, p.1-17.

PENHA FILHO, R.A.C.; FERREIRA, J.C.; KANASHIRO, A.M.I.; DARINI, A.L.D.; BERCHIERI, JR.A. Antimicrobial susceptibility of Salmonella Gallinarum and Salmonella Pullorum isolated from ill poultry in Brazil. Cienc. Rural, v.46, p.513-518, 2016.

QUINN, P.J.; CARTIER, M.E.; MARKEY, B. Salmonellas species. In: QUINN, P.J.; MARKEY, B.K.; LEONARD, F.C. et al. Clinical veterinary microbiology. London: Wolfe, 1994. p.237-242.

WIGLEY, P. Salmonella Enterica serovar Gallinarum: addressing fundamental questions in bacteriology sixty years on from the $9 \mathrm{R}$ vaccine. Avian Pathol., v.46, p.119-124, 2017. 